\title{
IMPLEMENTASI KETERBUKAAN INFORMASI PUBLIK PADA DINAS KEPENDUDUKAN DAN PENCATATAN SIPIL KABUPATEN SUMEDANG PROVINSI JAWA BARAT
}

\author{
Oleh \\ Septian Yudi Pratama ${ }^{1}$, \\ Etin Indrayani ${ }^{2}$, Rossy Lambelanova ${ }^{3}$ \\ ${ }^{1)}$ Institut Pemerintahan Dalam Negeri Kampus Tusa Tenggara Barat \\ Program Magister Terapan Studi Pemerintahan Daerah Institut Pemerintahan Dalam Negeri \\ septianpratma@ymail.com \\ 2,3) Institut Pemerintahan Dalam Negeri
}

\begin{abstract}
IMPLEMENTATION OF PUBLIC INFORMATION DISCLOSURE AT THE POPULATION AND CIVIL REGISTRATION OFFICE OF SUMEDANG REGENCY, WEST JAVA PROVINCE
\end{abstract}

In order to achieve public transparency, Sumedang Regency through the Regent Regulation
No. 97 of 2017 concerning the Management of Information and Documentation Services of
the Regional Government mandates every public agency to become an open organization by
placing Information and Documentation Management Officers (PPIDs) in each public agency. In
its implementation, this program has not been going well, a lot of information is the right of the
community but is not published, OPD as the spearhead of implementation seems less optimal in
carrying out the Public Information Openness (KIP) program, including one of the Population and
Civil Registration Services (Disdukcapil) of Sumedang Regency.
The results of this study indicate that (i) the implementation of the public information dis-
closure policy at the Department of Population and Civil Registration of Sumedang Regency has
not been effective due to limitations in using policy content and implementation context so that
the ideal public information disclosure has not been able to be realized; further more (ii) to en-
courage the implementation of the public information disclosure policy at the Sumedang Regency
Population and Civil Registration Office to make it more effective, it can refer to the stages of im-
plementing the public information policy initiated by the Open Government Partnership.

Keywords: implementation, public information opennes policy, information disclosure, public transparency

\section{AbSTRAK}

$\mathrm{D}^{\mathrm{s}}$ alam rangka mewujudkan transparansi publik, Kabupaten Sumedang melalui Peraturan Bupati No. 97 Tahun 2017 tentang Pengelola Pelayanan Informasi dan Dokumentasi Pemerintah Daerah mengamanatkan kepada setiap badan publik agar menjadi organisasi yang terbuka dengan menempatkan Pejabat Pengelola Informasi dan Dokumentasi (PPID) pada masing-masing badan publik. Dalam pelaksanaannya program ini belum berjalan dengan baik, banyak informasi yang menjadi hak masyarakat namun tidak dipublikasikan, OPD sebagai ujung 
tombak implementasi terkesan kurang maksimal dalam menjalankan program Keterbukaan Informasi Publik (KIP) ini termasuk salah satunya Dinas Kependudukan dan Pencatatan Sipil Kabupaten Sumedang. Hasil penelitian ini menunjukkan bahwa (i) implementasi kebijakan keterbukaan informasi publik di Dinas Kependudukan dan Pencatatan Sipil Kabupaten Sumedang belum berjalan efektif karena keterbatasan mempergunakan isi kebijakan dan konteks implementasi sehingga belum dapat terwujudnya keterbukaan informasi publik yang ideal; selanjutnya (ii) untuk mendorong implementasi kebijakan keterbukaan informasi publik di Dinas Kependudukan dan Pencatatan Sipil Kabupaten Sumedang agar lebih efektif dapat mengacu tahapan pelaksanaan kebijakan informasi publik yang digagas oleh Open Government Partnership

Kata kunci: implementasi, keterbukaan informasi publik, keterbukaan informasi, transparansi publik

\section{PENDAHULUAN}

$\mathrm{R}_{\mathrm{r}}^{\mathrm{e}}$ eformasi yang ditandai dengan runtuhnya Orde Baru menjadi sebuah awal yang penting terhadap perubahan yang dilandasi oleh keinginan segenap masyarakat untuk mewujudkan pemerintahan yang demokratis dan transparan menuju terwujudnya "good and clean governance". Kesungguhan dukungan terhadap penyelenggaraan pemerintahan yang demokratis dan transparan, salah satunya didorong oleh United Nations Development Agency (UNDP). ${ }^{1}$ UNDP (1997) menyebutkan, guna menuju "good governance" dan pemerintahan yang demokratis, salah satu prinsip atau karakteristik yang ditegaskan, yakni "transparency and accountability" atau biasa dikenal "transparan dan bertanggung jawab",' lebih lanjut Undang-Undang Keterbukaan Informasi Publik (UU KIP) menyebutkan "Penerapan keterbukaan informasi publik merupakan wujud dari penyelenggaraan negara demokratis yang mengedepankan kedaulatan rakyatnya. $^{3}$

Prinsip keterbukaan informasi publik secara resmi diberlakukan di Indonesia pada 2008 pasca disahkannya Undang-Undang No. 14 Tahun 2008 tentang Keterbukaan Informasi Publik. Hak masyarakat atas kebebasan informasi dapat dilihat dari dua pendekatan, yakni melalui pendekatan partisipasi masyarakat dan pendekatan akuntabilitas badan publik. Badan publik berkewajiban untuk menyebarluaskan rencana, aturan, produk kebijakan, dan hasil kelembagaannya kepada masyarakat luas, sedangkan masyarakat berkewajiban untuk memberikan informasi dan data mengenai diri atau lembaganya secara lengkap dan benar. Pada akhirnya tujuan utama dari pelaksanaan kewajiban, hak serta tanggung jawab dalam keterbukaan informasi publik ini adalah untuk mewujudkan good governance.

Sebelum diberlakukannya UU KIP, keterbatasan informasi dan ketidaktahuan masyarakat mengenai alur atau prosedur dalam pelayanan publik seringkali dimanfaatkan oleh oknum tertentu untuk mendapatkan keuntungan secara pribadi dengan melakukan pungutan-pungutan liar ataupun meminta imbalan secara ilegal. Informasi dianggap sebagai jasa yang mahal di mana hanya bisa didapatkan melalui jalurjalur tertentu yang nonformal, misalnya dengan memiliki kenalan seorang pejabat internal atau memiliki koneksi politik lainnya. Undang-undang KIP memberikan amanat kepada pejabat publik dan masyarakat bahwa dalam hal Keterbukaan Informasi Publik haruslah dilakukan pergeseran paradigma agar selaras dengan semangat reformasi yang sudah dinyalakan sejak sepuluh tahun sebelumnya. 
Dua tahun setelah diundangkannya UU KIP lahirlah Peraturan Pemerintah No. 61 Tahun 2010 tentang tata cara pelaksanaan kebijakan KIP yang selanjutnya ditindaklanjuti melalui Peraturan Menteri Dalam Negeri No. 35 Tahun 2010 tentang Pedoman Pengelolaan Informasi dan Dokumentasi di Lingkungan Kementerian Dalam Negeri dan Pemerintah Daerah yang merupakan pedoman bagi Pemerintah Daerah dalam mengimplementasikan UU KIP dan sebagai tindak lanjut rencana aksi Open Government Indonesia. Open Government Indonesia yang didirikan pada 20 September 2011 merupakan bagian dari aksi global Open Government Partnership (OGP) di mana bertujuan guna membangun pemerintahan yang lebih partisipatif, lebih inovatif, dan lebih transparan. ${ }^{4}$

Konsep Open Government dewasa ini berkembang dengan sangat pesat, Geiger \& Lucke $(2012)^{5}$ mengemukakan bahwa Open Government terdiri dari transparansi, partisipasi dan kerja sama pemerintah dengan para stakeholder. Open Government dipahami sebagai sistem pemerintahan yang lebih transparan, mudah diakses dan responsif, di mana informasi bergerak dengan bebas dari dan ke pemerintah, melalui berbagai media. Dalam sistem tersebut, berbagi informasi adalah norma dalam sektor publik dan sumber daya yang signifikan yang dikhususkan untuk penyebaran pengetahuan secara efektif dalam rangka pelayanan kepada masyarakat. Pembuat keputusan harus responsif terhadap kebutuhan, ide-ide dan prioritas masyarakat, dan memberikan sejumlah media yang efektif serta dapat diakses sebagai media aspirasi, dalam pendekatan ini tentu saja open government adalah sebuah gagasan/konsep yang sangat sejalan dengan Keterbukaan Informasi Publik.

Dalam kurun waktu kurang lebih sepuluh tahun pasca terbitnya aturan pelaksana untuk UU KIP masih terdapat begitu banyak permasalahan transparansi di Indonesia, dalam sektor pemerintahan, ketertutupan informasi dapat kita jumpai pada kasus perizinan serta pembuatan perda terkait pelaksanaan reklamasi pantai Jakarta. Jika ada keterbukaan informasi dari pemerintah dalam perencanaan pembangunan, maka ribuan nelayan tradisional tidak harus kehilangan mata pencaharian, rumah, dan lingkungan hidup, belum lagi hadiah dari dampak kerusakan alam yang ditimbulkannya. ${ }^{6}$

Penunjukan Pejabat Pengelola Informasi dan Dokumentasi (PPID) ${ }^{7}$ merupakan salah satu langkah lanjutan dalam pelaksanaan keterbukaan informasi publik. PPID memegang peranan penting dalam menjaga keberhasilan dan kesinambungan implementasi kebijakan KIP. Berdasarkan ketentuanUUKIP,PejabatPengelolaInformasi dan Dokumentasi merupakan pejabat yang bertanggung jawab di bidang penyimpanan, pendokumentasian, penyediaan, dan/atau pelayanan informasi pada badan publik. 8Dalam praktik pelaksanaannya PPID dilekatkan kepada pejabat struktural yang membidangi tugas dan fungsi pelayanan informasi dan dokumentasi atau kehumasan, dalam lingkup pemerintah daerah provinsi/ kabupaten/kota, PPID biasanya dijabat oleh Kepala Dinas Komunikasi dan Informasi (Kadis Kominfo) atau Kepala Biro Humas (di Provinsi) atau oleh Kepala Bagian Humas (di Kabupaten).

Informasi yang jelas, lengkap dan pasti akan sangat membantu masyarakat dalam memperoleh hak ataupun melaksanakan kewajibannya, misalnya dalam hal prosedur pembayaran pajak, semakin mudah prosedur pelaksanaan yang didukung oleh jelasnya informasi maka akan mempermudah masyarakat dalam melaksanakan kewajiban membayar pajak. Persoalan kependudukan dan pencatatan sipil juga seringkali menjadi polemik dan kendala untuk masyarakat dalam melaksanakan kewajiban serta memperoleh haknya, dalam penerbitan 
akta kelahiran dan kematian atau pembuatan KK dan KTP misalnya, karena kurangnya informasi yang jelas, pasti dan lengkap, masyarakat seringkali memilih untuk menunggu dalam jangka waktu yang tidak pasti atau menggunakan jasajasa penitipan ilegal yang seharusnya tidak perlu dan cenderung merugikan masyarakat.

Kependudukan dan pencatatan sipil (dukcapil) adalah salah satu urusan konkuren wajib non-pelayanan dasar yang diamanatkan kepada pemerintah melalui Undang-Undang No. 23 Tahun 2014 tentang Pemerintah Daerah, ${ }^{9}$ seperti halnya urusanurusan pemerintah yang lain, dukcapil juga merupakan pelayanan yang penting bagi masyarakat, dinas dukcapil melaksanakan registrasi dan pencatatan tentang peristiwaperistiwa penting manusia sejak dilahirkan, mulai berkeluarga, pindah-datang bahkan sampai dengan meninggal dunia. Melihat dari urgensi pentingnya pendataan dukcapil maka perlu didukung secara maksimal oleh keterbukaan informasi publik melalui media Website atau media sosial.

Website resmi menjadi salah satu jendela di mana pemerintah dan masyarakat bisa saling berinteraksi. Pemerintah menyediakan portal yang berisi informasi yang menjadi hak publik dengan turut serta mencantumkan kolom untuk komentar sehingga masyarakat bisa menyampaikan keluhan-keluhan, usul, saran, ide, gagasan dan tentu saja pemerintah wajib mendengarkan serta memberikan tanggapan. Rocky Gerung $^{10}$ dalam tribunnews mengatakan bahwa "Pemerintah itu harus selalu siap dikritik, kalau bisa dua puluh jam jam sehari", pernyataan dari pengamat politik ini mengindikasikan bahwasanya setiap saat pemerintah harus selalu siap untuk mendengarkan pengaduan berupa keluh kesah atau usul saran masyarakat, kemudian mengolah informasi yang didapat serta tidak lupa memberikan tanggapan dan solusi. Selain via website penulis juga melakukan pencarian informasi terkait keterbukaan Informasi Publik Disdukcapil Sumedang pada media sosial mainstream di antaranya, Youtube, Facebook, Instagram, Twitter, dan juga Whatsapp.

Penulis tertarik untuk melakukan pengamatan yang lebih mendalam terkait ketersediaan informasi pada urusan kependudukan dan pencatatan sipil di Kabupaten Sumedang, pasalnya produkproduk kependudukan dan pencatatan sipil adalah dokumen resmi yang sangat penting bagi masyarakat sebagai identitas dan persyaratan administratif pada berbagai macam urusan dalam bernegara dan bermasyarakat. Hal ini juga didukung oleh tingginya tingkat laporan dan pengaduan masyarakat sumedang dalam website LAPOR Kabupaten Sumedang terkait urusan kependudukan dan pencatatan sipil jika dibandingkan dengan urusan lainnya. ${ }^{11}$ Kabupaten Sumedang juga merupakan salah satu Kabupaten yang berbatasan langsung dengan Ibu Kota Provinsi Jawa Barat, yakni Kota Bandung yang selama ini telah terlebih dahulu menunjukkan dan membuktikan semangat Keterbukaan Informasi Publik, satu sisi hal ini baik secara geografis karena letak yang berdekatan Kabupaten Sumedang bisa dengan mudah untuk belajar atau bekerja sama dengan Kota Bandung, satu sisi juga akan buruk manakala masyarakat menilai dari sisi di mana jarak berdekatan dengan ibu kota provinsi tapi kualitas pelayanan keterbukaan informasi publiknya berbeda jauh. Atas permasalahan tersebut penulis melalui tulisan ini ingin melihat bagaimana implementasi keterbukaan informasi publik pada dinas dukcapil sumedang yang pada akhirnya bermuara pada meningkatnya kualitas pelayanan publik.

Adapun rumusan masalah yang ingin penulis gali dalam tulisan ini adalah

a. Bagaimana Implementasi Kebijakan Keterbukaan Informasi Publik di 
lingkungan Dinas Kependudukan dan Pencatatan Sipil Kabupaten Sumedang?

b. Bagaimana mendorong upaya Dinas Kependudukan dan Pencatatan Sipil dalam meningkatkan Implementasi Keterbukaan Informasi Publik di Kabupaten Sumedang?

Terkait hal tersebut tujuan penulisan juga sepadan dengan rumusan masalah, yaitu Untuk menganalisis bagaimana Implementasi Kebijakan Keterbukaan Informasi Publik yang dilaksanakan oleh Dinas Kependudukan dan Pencatatan Sipil Kabupaten Sumedang serta untuk menganalisis bagaimana mendorong upaya Dinas Kependudukan dan Pencatatan Sipil dalam meningkatkan implementasi kebijakan keterbukaan informasi publik di Kabupaten Sumedang

\section{METODE PENELITIAN}

Paradigma yang digunakan dalam penelitian ini adalah paradigma postpositivist. Menurut Egon G. Guba dalam Parsons bahwa penelitian post-positivist merupakan penelitian yang memandang realitas eksis, tetapi tidak bisa dipahami atau diterangkan secara menyeluruh, melainkan hanya bisa diperkirakan. ${ }^{12}$ Post-positivist bersandar pada banyak metode sebagai cara menangkap sebanyak mungkin realitas, pada saat yang bersamaan, dilakukan penekanan pada penemuan dan verifikasi teori. ${ }^{13}$ Pendekatan post positivis digunakan untuk mencapai sebuah pemahaman yang mendalam (insight) dan menyeluruh (whole) terhadap fenomena yang terjadi melalui proses wawancara mendalam dan observasi partisipasi dalam memahami makna fenomena yang ada tersebut serta makna simbolis di balik realita yang ada. ${ }^{14}$

Dengan pendekatan ini peneliti dapat menjajaki secara lebih mendalam objek yang akan diteliti. Peneliti dituntut untuk banyak terjun langsung melihat kondisi di lapangan dan mengadakan proses interaksi langsung kepada aktor-aktor pelaksana kebijakan keterbukaan informasi publik di lingkungan Pemerintah Kabupaten Sumedang khususnya di instansi Dinas Kependudukan dan Pencatatan Sipil Kabupaten Sumedang. Tentunya dengan pendekatan ini diharapkan mampu mendeskripsikan secara objektif dan seakurat mungkin mengenai permasalahan implementasi Kebijakan Keterbukaan Informasi Publik di Dinas Kependudukan dan Pencatatan Sipil Kabupaten Sumedang.

Desain penelitian yang penulis gunakan dalam penelitian ini, yakni deskriptifkualitatif. Studi penelitian deskriptif digunakan guna menemukan fakta melalui penafsiran yang tepat. ${ }^{15}$ Penelitian deskriptif memusatkan perhatian kepada masalah aktual dan peneliti berusaha mendeskripsikan peristiwa dan kejadian yang menjadi pusat perhatian tanpa memberikan perlakuan khusus terhadap peristiwa tersebut. ${ }^{16}$

Peneliti memilih menggunakan pendekatan kualitatif dalam penelitian ini karena dianggap sesuai dengan paradigma dan permasalahan yang ada pada Dinas Kependudukan dan Pencatatan Sipil Kabupaten Sumedang. Dalam penelitian kualitatif ini, memungkinkan peneliti untuk dapat berinteraksi secara langsung dan melakukan wawancara secara mendalam terhadap aktor-aktor dalam implementasi kebijakan keterbukaan informasi publik Dinas Kependudukan dan Pencatatan Sipil Kabupaten Sumedang, sehingga peneliti dapat mengumpulkan data selengkaplengkapnya berdasarkan fenomenafenomena serta fakta-fakta yang secara langsung dirasakan oleh peneliti. 


\section{HASIL DAN PEMBAHASAN}

Dalam hal implementasi KIP akan menjadi penting untuk menelaah bagaimana regulasi induk serta turunannya telah diaplikasikan. Undang-Undang No. 14 Tahun 2008 yang kemudian djabarkan lebih lanjut dalam Peraturan Bupati Sumedang No. 97 Tahun 2017 tentang Pengelolaan Pelayanan Informasi dan Dokumentasi Pemerintah Daerah di lingkungan Dinas Kependudukan dan Pencatatan Sipil Kabupaten Sumedang adalah payung hukum kebijakan ini, melalui analisis terhadap faktor-faktor yang memengaruhi keberhasilan implementasi kebijakan keterbukaan informasi publikyang digagas oleh Grindle penulis menemukan informasi-informasi yang kemudian penting untuk dituangkan dalam tulisan ini.

Teori Grindle mengidentifikasi ada 2 (dua) hal faktor penting yang memengaruhi keberhasilan suatu implementasi kebijakan publik ada dua, yaitu content of policy (isi kebijakan) dan context of implementation (lingkungan implementasi). Grindle menjelaskan lebih lanjut bahwa aspek penting dalam aktivitas implementasi kebijakan tersebut meliputi: $a$. Content of Implementation (Isi Kebijakan): 1) interests affected (kepentingan yang terpengaruh kebijakan) ;2) type of benefits (Jenis manfaat yangdihasilkan);3) extentofchangeenvisioned (derajat perubahan yang diinginkan); 4) site of decision making(kedudukan pembuat kebijakan); 5) program Implementors (para pelaksana program); 6) resources committee (sumber daya yang dikerahkan); $b$. Context of Implementation (konteks kebijakan): 1) power, interests, and strategies of actors involved (kekuatan, kepentingan strategis aktor yang terlibat; 2) institution and regime characteristics (karakteristik lembaga dan penguasa); 3) compliance and responsiveness (kepatuhan dan daya tanggap pelaksana). ${ }^{17}$

\section{Isi Kebijakan (Content of Policy)}

Dalam peraturan Bupati Sumedang No. 97 Tahun 2017 tentang Pengelolaan
Pelayanaan Informasi dan Dokumentasi Pemerintah Daerah yang merupakan aturan teknis pelaksana atau turunan dari Undang-Undang No. 14 Tahun 2008 tentang Keterbukaan Informasi Publik, telah diterangkan dengan runtut dan jelas tentang bagaimana pembagian peran dan fungsi, kewajiban serta alur tata laksana dalam hal keterbukaan informasi publik di lingkup Pemerintah Kabupaten Sumedang. Regulasi tersebut menjadi pedoman baku untuk setiap pelaksana kebijakan demi tercapainya derajat perubahan yang diharapkan, penting juga untuk selalu mengacu pada kebijakan tersebut agar setiap OPD dalam operasionalisasi Keterbukaan Informasi Publik menyiapkan dengan sebaik-baiknya sumber daya yang dimiliki, baik kompetensi SDM, anggaran atau fasilitas-fasilitas lainnya.

\section{- Kepentingan yang Terpengaruh Kebijakan (Interests Affected)}

Kepentingan yang terpengaruh bukan hanya sebatas pada pengelola APBN atau APBD, namun lebih luas ke arah pembuat kebijakan, dan juga para pihak yang menjalankan tugas-tugas yang bersinggungan dengan kepentingan publik misalnya pengurus masjid, karang taruna dan juga partai politik. Grindle mengemukakan bahwa secara umum, tugas implementasi kebijakan adalah untuk membangun hubungan yang membantu tujuan-tujuan dari kebijakan publik agar terealisasi sebagai hasil aktivitas pemerintahan. ${ }^{18}$

Implementasi kebijakan keterbukaan informasi publik di Kabupaten Sumedang dilaksanakan oleh seluruh Organisasi Perangkat Daerah di lingkungan Kabupaten Sumedang, kepentingan siapa saja yang terpengaruh dalam implementasi tersebut dapat dilihat secara jelas dari tujuan program tersebut. Berdasarkan Pasal 3 UU KIP bahwa:

Tujuan kebijakan KIP di antaranya meliputi jaminan hak warga negara untuk mengetahui rencana pembuatan 
kebijakan publik, program kebijakan publik, dan proses pengambilan keputusan publik, serta alasan pengambilan suatu keputusan publik; Mendorong partisipasi masyarakat dalam proses pengambilan kebijakan publik; Meningkatkan peran aktif masyarakat dalam pengambilan kebijakan publik dan pengelolaan Badan Publik yang baik; Mewujudkan penyelenggaraan negara yang baik, yaitu yang transparan, efektif dan efisien, akuntabel serta dapat dipertanggungjawabkan; Mengetahui alasan kebijakan publik yang memengaruhi hajat hidup orang banyak; Mengembangkan ilmu pengetahuan dan mencerdaskan kehidupan bangsa; dan/atau Meningkatkan pengelolaan dan pelayanan informasi di lingkungan Badan Publik untuk menghasilkan layanan informasi yang berkualitas. ${ }^{19}$

Tujuan kebijakan KIP menjelaskan kepentingan yang terpengaruh adalah seluruh warga negara karena hak warga negara untuk mengetahui proses pembuatan kebijakan hingga evaluasi kebijakan.

\section{- Jenis Manfaatyangakan Dihasilkan Implementasi Kebijakan (Type of Benefits)}

Dalam kaitannya dengan penyediaan informasi publik, secara umum manfaatnya adalah menjamin bukti nyata demokrasi serta terlidunginya hak masyarakat untuk ikut serta dalam pembangunan dengan mengetahui proses pembuatan kebijakan hingga turut serta dalam mengevaluasi kebijakan. Dari sudut pandang pimpinan Disdukcapil keterbukaan ini dapat merubah mindset pimpinan serta meluaskan cakrawala berpikir bagi seorang pimpinan terutama dalam mengambil sebuah kebijakan.

Penulis mendapati bahwa terdapat harapan besar dari internal organisasi akan manfaat yang akan dihasilkan dengan pelaksanaan kebijakan KIP ini di antaranya dapat merubah mindset tentang hak dalam memperoleh informasi serta memberikan manfaat sebanyak-banyaknya kepada publik, memunculkan komunikasi dua arah antara pemerintah dengan masyarakat, namun beriring dengan hal tersebut muncul pula kekhawatiran akan potensi penyalahgunaan informasi yang barangkali bisa dilakukan oleh oknum-oknum yang tidak bertanggung jawab yang mengambil informasi secara tidak utuh kemudian menyebarluaskannya dengan tujuan mendapat/tidak mendapatkan keuntungan.

Lazonder, Biemans, \& Wopereis (2000) menyatakan bahwa:

Terdapat perbedaan antara seseorang yang memiliki keahlian khusus dalam menggunakan search engine dengan orang yang masih baru atau awam dalam menggunakan search engine. Mereka dibedakan oleh pengalaman yang dimiliki. Individu yang memiliki pengalaman lebih banyak dalam memanfaatkan search engine, akan cenderung lebih sistematis dalam melakukan penelusuran dibandingkan dengan yang masih minim pengalaman (novice) $^{20}$

Dari teori tersebut dapat dipahami bahwasanya sangat penting untuk melaksanakan edukasi kepada publik dalam sistematika memperoleh informasi yang benar, bukan Hoaks. Guru Besar Psikologi Universitas Airlangga (Unair) Surabaya, Prof. Dr. Cholichul Hadi, Msi mengatakan "Munculnya berita palsu atau hoaks adalah bagian dari dampak negatif penyalahgunaan teknologi informasi”. Menurutnya, hoaks tidak dapat dihentikan seratus persen sebab dari dulu berita palsu atau fitnah menjadi bagian dari arus kehidupan manusia. Hal yang bisa dilakukan hanya mengurangi agar tidak terus bergejolak di masyarakat. ${ }^{21}$

\section{- Perubahan yang akan Diwujudkan (Extent of Change Envision)}

Perubahan yang ingin dicapai dalam kebijakan keterbukaan informasi publik 
lebih ke arah pemahaman tentang standar operasional, yakni masyarakat dapat secara jelas mengetahui alur pelayanan serta persyaratan-persyaratan yang dibutuhkan dalam pelayanan publik. Misalnya dalam hal pembuatan/penerbitan dokumen kependudukan atau pencatatan sipil, dengan mengetahui persyaratan serta alur prosedur pelayanan tentunya akan memudahkan masyarakat ataupun pihak Disdukcapil Sumedang. Perubahan yang diinginkan Disdukcapil Sumedang selaku badan publik adalah menjadi badan publik yang terbuka sehingga mampu memberikan pelayanan yang terbaik sesuai tugas dan fungsi, memberikan informasi kepada masyarakat. Secara umum perubahan yang diharapkan, yaitu sistem, proses, dan prosedur kerja yang jelas, efektif dan efisien dalam rangka pelayanan kepada masyarakat.

\section{- Letak Pengambilan Keputusan (Site of Decision Making )}

Para pelaksana Keterbukaan Informasi Publik pada tingkatan OPD dibebankan kepada Pejabat yang mengelola informasi dan dokumentasi pada OPD masingmasing, hal tersebut sesuai dengan yang diamanatkan Perbup Sumedang No. 97 Tahun 2017 Pasal 5 ayat (1), pada poin (d) disebutkan bahwa "PPID pembantu dijabat oleh pejabat pada perangkat daerah yang mengelola informasi dan dokumentasi". ${ }^{22}$ Pada Disdukcapil Kabupaten Sumedang jabatan PPID pembantu diamanatkan kepada Sekretaris Disdukcapil.

Letak pengambilan keputusan merupakan salah satu pokok penting dalam suatu implementasi kebijakan publik. PPID pembantu yang dijabat oleh sekretaris dinas Disdukcapil memberikan wewenang kepada beliau untuk melaksanakan pengaturan teknis lebih lanjut terkait KIP di Disdukcapil Sumedang, sehingga baik atau buruknya implementasi KIP ini salah satunya bergantung kepada manajemen dari PPID pembantu selaku pengambil keputusan.

\section{- Para Pelaksana Program (Program Implementer)}

Kebijakan Keterbukaan Informasi Publik pada Pemerintah Kabupaten Sumedang menjadi tugas dan tanggung jawab utama dari PPID Utama, yaitu Kepala Bagian Humas dan Protokol Setda Kabupaten Sumedang. Walaupun dalam beberapa pendapat disampaikan bahwa sebenarnya paradigma antara Keterbukaan Informasi Publik dengan Kehumasan itu tidak sejalan, KIP berorientasi pada penyebarluasan seluruh informasi secara meluas tanpa batas (kecuali yang dikecualikan) sedangkan paradigma kehumasan meletakkan informasi yang disebarkan hanya sebatas yang positif dan bisa memperkuat posisi politik pemerintah, lebih kepada salah satu cara untuk menjaga eksistensi dan pencitraan. Posisi PPID utama yang kurang ideal menurut beberapa pihak harus tetap dijalankan, sebab merupakan amanah langsung dari peraturan bupati sumedang No. 97 Tahun 2017.

Pada Disdukcapil Kabupaten Sumedang, PPID pembantu yang dijabat oleh sekretaris dinas bisa mengordinasikan antar bidang di bawahnya dengan lebih cepat. Para pelaksana program di Disdukcapil adalah seluruh pegawai, seluruhnya memiliki peran masing-masing. Yang berada pada bidang kependudukan memastikan data-data dan informasi kependudukan dapat diolah dengan baik, pada pencatatan sipil juga demikian.

\section{- Sumber Daya yang Tersedia (Resources Committed)}

Sumber daya yang dikerahkan dalam pelaksanaan kebijakan KIP dapat diidentifikasi menjadi tiga jenis yaitu, kebijakan, sumber daya manusia dan anggaran. Pertama, kebijakan dalam menindaklanjuti UU KIP sangat dipengaruhi oleh kepemimpinan dalam institusi pelaksana. Bidang PIAK dan Data selaku bidang pelaksana kebijakan KIP sekarang ini 
belum begitu memperhatikan aturan teknis terkait layanan Informasi Publik termasuk SOP yang jelas mengenai Layanan Informasi Publik pada Disdukcapil Sumedang. Kedua, sumber daya manusia yang melaksanakan kebijakan KIP tergolong minim, minim dalam hal pemahaman/kompetensi dan kuantitas. Sumber daya manusia yang secara khusus telah mengikuti Diklat tentang pelayanan informasi belum ada, dan aparatur yang secara khusus menangani pelayanan informasi publik pun belum tersedia. Ketiga, alokasi anggaran dalam pelaksanaan kebijakan keterbukaan informasi publik masih terbatas pada pelaksanaan kegiatan yang melekat di bidang masing-masing, belum ada alokasi yang khusus.

\section{Lingkungan Implementasi (Context of Implementation)}

Dalam konteks implementasi Keterbukaan Informasi Publik pada Dinas Kependudukan dan Pencatatan Sipil Kabupaten Sumedang sangat bergantung dengan kepentingan penguasa serta karakteristik lembaga yang menjalankannya, semakin penting informasi yang hendak dipublikasikan semakin dalam juga potensi kritik yang akan didapatkan manakala informasi tersebut dianggap kurang oleh masyarakat.

- Kekuasaan, Kepentingan, dan Strategi Pelaksana yang Terlibat (Power, Interest, and Strategy of Actor Involved )

Kekuasaan, kepentingan, dan strategi pelaksana yang terlibat untuk mengimplementasikan kebijakan KIP perlu memperhatikan interaksi lingkungan, tujuan dan informasi. Interaksi lingkungan implementasi kebijakan KIP, yaitu interaksi kerja sama antar pelaksana, yaitu Atasan PPID, PPID dan masyarakat yang menjadi pemohon informasi. Tujuan implementasi kebijakan KIP diarahkan kepada Disdukcapil Sumedang sendiri sebagai badan publik dan masyarakat agar tercipta kepercayaan masyarakat dalam setiap pengelolaan Anggaran pada Disdukcapil Sumedang.

Implementasi kebijakan KIP tidak bisa dicapai secara maksimal jika hanya dilakukan oleh PPID saja. Strategisnya harus dilakukan secara bersama-sama, PPID Utama/Atasan PPID berkoordinasi dengan PPID dan tiaptiap bidang pada Disdukcapil. Dan pada masing-masing bidang yang membantu mencarikan tugas akan tunduk apabila ditunjuk dalam Surat Tugas/SK.

\section{- Karakteristik Lembaga dan Penguasa (Institution and Regime Characteristic)}

Disdukcapil Sumedang sebagaimana yang diamanatkan Undang-Undang No. 24 Tahun 2013 tidak sedikit pun menarik pembiayaan kepada masyarakat dalam setiap pengurusan, urusan apa pun itu, yang datang hanya untuk bertanya dan pengaduan, ataupun yang butuh dokumen-dokumen kependudukan dilayani sesuai tugas pokok dan fungsi, paradigma-paradigma lama di mana pengurusan dokumen via calo-calo ilegal atau praktik sogok menyogok demi kemudahan sudah sejak lama dilarang dan tertibkan. Dari pernyataan tersebut dapat dipahami bahwa salah satu karakteristik Disdukcapil adalah non provit, tidak ada konsep laba yang berusaha didapatkan dengan cara legal apalagi ilegal, prioritas utama adalah untuk memberikan pelayanan kepada masyarakat secara maksimal.

\section{- Kepatuhan dan Daya Tanggap Pelaksana (Compliance and Responsiveness )}

Menurut Grindle (1980) ${ }^{23}$ bahwa "terdapat dua faktor yang paling penting dalam implementasi efektif pada program pemerintah, yaitu personel yang terlatih secara kompeten dan tersedia jumlah personelnya". Untuk mencapai implementasi efektif yang didasarkan pada kedua faktor tersebut, distribusi personel berkualitas 
dan memiliki motivasi tinggi pada setiap tingkatan implementasi dilakukan secara merata, adil dan sesuai kebutuhan organisasi. Hal ini sebagai upaya untuk menciptakan kepatuhan dan daya tanggap personel sebagai pelaksana implementasi kebijakan KIP. Pelaksanaan pelayanan informasi di Disdukcapil Sumedang belum didukung oleh sumber daya manusia yang memadai baik secara kuantitas apalagi kualitas. Untuk itu jabatan fungsional tertentu, yaitu pranata humas sangat dibutuhkan. Loyalitas dan konsistensi implementasi kebijakan KIP harus didukung keahlian dan keterampilan pelaksana sebagai modal untuk mewujudkan ke arah yang lebih baik.

\section{Dinas Kependudukan dan Pencatatan Sipil dalam Mendorong Upaya Implementasi Keterbukaan Informasi Publik di Kabupaten Sumedang}

Proses mendorong pelaksanaan kebijakan Keterbukaan Informasi Publik di Disdukcapil Sumedang dibahas berdasarkan pendapat yang dikemukakan oleh Open Government Partnership tentang tahapan pelaksanaan ketebukaan informasi publik di Badan Publik. Tahapan tersebut terdiri dari 4 tahapan, yaitu tahapan initial, tahapan intermediet, tahapan advance, dan tahapan innovation. ${ }^{24}$

\section{Tahapan Initial}

\section{- Membuat Regulasi Terkait Pelak- sanaan KIP}

Indonesia telah memiliki UndangUndang No. 14 Tahun 2008 tentang Keterbukaan Informasi Publik. Dalam melaksanakan kebijakan selanjutnya pemerintah menerbitkan Peraturan Pemerintah No. 61 Tahun 2010 tentang tata cara pelaksanaan kebijakan KIP yang kemudian ditindaklanjuti melalui Peraturan Menteri Dalam Negeri No. 35 Tahun 2010 tentang Pedoman Pengelolaan Informasi dan Dokumentasi di Lingkungan
Kementerian Dalam Negeri dan Pemerintah Daerah. Sebagai tindak pada 2017 Bupati Sumedang menerbitkan Perbup No. 97 Tahun 2017 tentang Pengelolaan Pelayanan Informasi dan Dokumentasi Pemerintah Daerah dan kemudian lebih ditegaskan lagi dalam Surat Keputusan Bupati Sumedang No. 489/KEP.479-HUK/2017 tentang Susunan Pengelola Layanan Informasi dan Dokumentasi Pada Pemerintah Kabupaten Sumedang.

\section{- Membuat Struktur yang Melak- sanakan Kebijakan KIP}

Disdukcapil Sumedang menunjuk Bidang PIAK dan Pemanfaatan data dan sebagai unit penanggung jawab pelaksana Kebijakan KIP di Disdukcapil Sumedang berdasarkan surat disposisi dari Sekretaris Dinas saja untuk menjalankan tugas-tugas PPID, dengan pertimbangan bahwa PIAK memiliki karakteristik kesamaan dengan tugas PPID dan memang tugas-tugas layanan informasi.

\section{- Menyediakan Pendidikan dan Pelatihan untuk Pegawai yang Bertugas Menjalankan Kebijakan KIP}

Untuk kegiatan intern Disdukcapil Sumedang juga melaksanakan rapat/ workshop dengan mengundang pemateri dari Diskominfo/KID/LSM yg menangani KIP. Untuk efektivitas diklat tersebut disadari oleh pihak Disdukcapil belum memberikan hasil yang signifikan dalam meningkatkan kualitas pelayanan informasi di Disdukcapil Sumedang.

\section{- Memuat Informasi Inti Terkait Pemerintah Secara Proaktif}

Disdukcapil Sumedang telah memiliki website https: //disdukcapil.sumedangkab. go.id yang berisi profil, layanan, Informasi Publik, Galeri, dan Peraturan-peraturan. Sayangnya memang website ini hanya menampilkan informasi publik berupa 
pengumuman, rencana strategis, laporan keuangan, laporan kinerja, dan informasi lelang. Secara umum sudah bagus akan tetapi belum menampilkan spesifikasi daftar informasi publik yang diumumkan secara berkala, informasi publikyang dipublikasikan secara serta merta dan informasi yang diumumkan setiap saat. Dalam hal ini secara umum Disdukcapil Sumedang telah memuat informasi inti terkait pemerintah secara proaktif melalui media website. Selain melalui website, Disdukcapil juga menyebarluaskan informasi kepada publik melalui media yang lebih efektif, yaitu media sosial

\section{Tahap Intermediet}

- Memastikan Setiap Komponen dalam Bidang Publik Melaksanakan Kebijakan KIP

Disdukcapil Sumedang dalam memonitor pelaksanaan kebijakan KIP melaksanakan rapat monitoring dan evaluasi tahunan, namun rapat ini dirasa kurang efektif disebabkan kurang proporsionalnya peserta yang hadir secara jumlah dan fungsi.

\section{- Memperluas Publikasi Informasi Secara Proaktif}

Disdukcapil Sumedang sejauh ini telah mengembangkan website serta media sosial mainstream Disdukcapil secara bertahap yang merupakan media untuk memperluas informasi secara proaktif.

\section{- Mempromosikan Kepedulian Masyarakat terhadap Hak Atas In- formasi}

Disdukcapil Sumedang menyadari bahwa selama ini terlalu fokus untuk mengelola badan publik, namun masyarakat luas belum memahami secara baik makna dari keterbukaan informasi publik. Dalam beberapa kesempatan telah disampaikan ke Pemerintah Kabupaten untuk mendukung dan mempromosikan kepedulian masyarakat terhadap hak atas informasi. Namun dari sisi Disdukcapil Sumedang sendiri, pertanyaan tersebut belum terjawab, sehingga disimpulkan Disdukcapil Sumedang belum ada tindakan nyata terkait mempromosikan kepedulian hak atas informasi karena merasa bukan tanggung jawabnya.

\section{Tahap Advance}

\section{- Menyesuaikan Aturan yang Ada terhadap Standar International}

Aturan yang ada saatini pada Disdukcapil Sumedang telah secara sistematis diuraikan dari aturan-aturan di atasnya, baik dari Surat Keputusan Bupati Sumedang, Perbup Sumedang, Permendagri, Peraturan Pemerintah, sampai dengan Undang-Undang KIP yang seharusnya sudah mengacau pada isu-isu global.

\section{- Menyusun Sistem Monitoring dan Evaluasi dalam Penerapan Kebijakan KIP}

Hasil evaluasi memiliki peran sebagai bahan diskusi dalam perbaikan baik pada tahap pembuatan regulasi sampai dengan implementasi dan untuk mendapatkan hasil yang lebih maksimal pada tahapan evaluasi dibutuhkan anggaran juga yang memang dialokasikan secara khusus untuk mendukung monitoring dan evaluasi tersebut baik internal ataupun eksternal.

\section{- Meninjau Ulang dan Merevisi Kebijakan yang Ada}

Sebagai payung hukum lokal sebenarnya peraturan Bupati terkait KIP tersebut sudah cukup mendetail dalam mengatur pelaksanaan dan pelaksana kebijakan KIP pada Kabupaten Sumedang namun salah satu hal pokok yang sering menjadi wacana dalam perdebatan adalah eselonoring dari pejabat PPID utama yang dijabat oleh Kepala Bagian Humas Setda Kabupaten Sumedang, sebagian sepaham dengan hal tersebut namun sebagian lagi lebih cenderung setuju 
jika jabatan tersebut diletakkan pada Kepala Diskominfo.

\section{Tahap Innovative}

\section{- Menggunakan IT untuk Mening- katkan Akses terhadap Informasi.}

Disdukcapil telah menyadari pentingnya penerapan TI dalam pelayanan informasi, namum terdapat banyak hambatan yang membuat website dan media sosial yang sudah ada belum maksimal., salah satu hambatan utama, yaitu ketersediaan SDM yang mumpuni dalam bidang tersebut. Penulis kembali mengutip pendapat dari Dunn yang menjelaskan proses implementasi suatu kebijakan, "Kebijakan diadopsi menjadi program oleh unit administratif, didukung mobilitas finansial yang memadai, dan sumber daya manusia sebagai implementor, dengan kepatuhan terhadap kebijakan itu sendiri". ${ }^{25}$ Sumber daya manusia sebagai implementor berperan penting dalam proses implementasi kebijakan tersebut, SDM yang kompeten tentu saja akan meningkatkan peluang keberhasilan suatu implementasi kebijakan pun demikian SDM yang buruk hanya akan menghambat proses atau menggagalkan implementasi kebijakan publik tersebut.

\section{SIMPULAN}

Implementasi kebijakan KIP di Dinas Kependudukan dan Pencatatan Sipil Kabupaten Sumedang belum berjalan dengan efektif dikarenakan keterbatasan dalam mempergunakanisikebijakan danlingkungan implementasi, birokrasi dalam rangka implementasi KIP di lingkungan Disdukcapil penulis nilai masih belum terstruktur dengan baik, tumpang tindih tupoksi masih menjadi persoalan klasik, ketersediaan SDM yang kurang memadai secara grafik usia dan pengalaman dalam mengikuti pelatihanpelatihan, serta alokasi anggaran yang belum difokuskan untuk KIP juga menjadi faktor terhambatnya implementasi KIP tersebut. Dalam menganalisis menggunakan teori Grindle, penulis menemukan salah satu kekurangan dari teori Grindle, yaitu belum menggambarkan kondisi "Culture of Bureaucracy" atau "Budaya Birokrasi" yang sangat berpengaruh terhadap pelaksanaan KIP.

Dinas Kependudukan dan Pencatatan Sipil Kabupaten Sumedang sekarang ini cenderung masih berada pada tahapan initial atau tahap awal dalam tahapan menuju keterbukaan informasi publik, sementara pada tahapan-tahapan selanjutnya terlihat belum maksimal. Untuk mendorong terwujudnya implementasi kebijakan KIP di Dinas Kependudukan dan Pencatatan Sipil Kabupaten Sumedang dapat mengacu tahapan dalam pelaksanaan kebijakan informasi publik yang digagas oleh Open Government Partnership.

Terdapat beberapa hal yang disarankan oleh penulis dalam rangka perbaikan implementasi kebijakan KIP di Dinas Kependudukan dan Pencatatan Sipil Kabupaten Sumedang, antara lain:

a. Membuat Peraturan Kepala Dinas terkait pedoman pengelolaan pelayanan informasi dan dokumentasi di lingkungan Dinas Kependudukan dan Pencatatan Sipil Kabupaten Sumedang dengan mengakomodasi perkembangan regulasi KIP terkini.

b. Menegaskan penunjukan PPID Dinas Kependudukan dan Pencatatan Sipil Kabupaten Sumedang sehingga mengikat perorangan sebagai pengelola KIP dengan mempertimbangkan keterwakilan masing-masing bidang agar memudahkan koordinasi, monitoring dan evaluasi implementasi kebijakan KIP;

c. Menyusun program yang jelas dapat berupa mengikutsertakan aparatur yang menjadi ujung tombak pelayanan informasi dan dokumentasi dalam 
pendidikan dan pelatihan pelayanan informasi dan dokumentasi yang diselenggarakan oleh Dinas Komunikasi, Informasi dan Informatika maupun pihak lain;

d. Perlunya menyusun SOP mekanisme pengelolaan pelayanan informasi dan dokumentasi PPID yang terintegrasi dengan layanan informasi kependudukan dan pencatatan sipil guna menggambarkan secara jelas uraian prosedur, para pelaksana, dan mutu baku yang menjelaskan kelengkapan, waktu pelayanan dan output yang dihasilkan;

e. Menciptakan ruang layanan informasi yang representatif di Dinas Kependudukan dan Pencatatan Sipil Kabupaten Sumedang;

f. Membangun website khusus PPID Dinas Kependudukan dan Pencatatan Sipil Kabupaten Sumedang sebagai media yang menjembatani permintaan informasi publik;

g. Membuat video animasi atau tutorial alur prosedur pelayanan setiap urusan kependudukan dan pencatatan sipil, setiap kegiatan Dinas Kependudukan dan Pencatatan Sipil Kabupaten Sumedang kemudian diunggah serta disebarluaskan melalui sosial media terutama Youtube, Facebook dan Instagram.

\section{SARAN}

Terdapat beberapa hal yang disarankan oleh penulis dalam rangka perbaikan implementasi kebijakan KIP di Dinas Kependudukan dan Pencatatan Sipil Kabupaten Sumedang, antara lain:

a. Membuat Peraturan Kepala Dinas terkait pedoman pengelolaan pelayanan informasi dan dokumentasi di lingkungan Dinas Kependudukan dan Pencatatan Sipil Kabupaten Sumedang dengan mengakomodasi perkembangan regulasi KIP terkini.

b. Menegaskan penunjukan PPID Dinas Kependudukan dan Pencatatan Sipil Kabupaten Sumedang sehingga mengikat perorangan sebagai pengelola KIP dengan mempertimbangkan keterwakilan masing-masing bidang agar memudahkan koordinasi, monitoring dan evaluasi implementasi kebijakan KIP;

c. Menyusun program yang jelas dapat berupa mengikutsertakan aparatur yang menjadi ujung tombak pelayanan informasi dan dokumentasi dalam pendidikan dan pelatihan pelayanan informasi dan dokumentasi yang diselenggarakan oleh Dinas Komunikasi, Informasi dan Informatika maupun pihak lain;

d. Perlunya menyusun SOP mekanisme pengelolaan pelayanan informasi dan dokumentasi PPID yang terintegrasi dengan layanan informasi kependudukan dan pencatatan sipil guna menggambarkan secara jelas uraian prosedur, para pelaksana, dan mutu baku yang menjelaskan kelengkapan, waktu pelayanan dan output yang dihasilkan;

e. Menciptakan ruang layanan informasi yang representatif di Dinas Kependudukan dan Pencatatan Sipil Kabupaten Sumedang;

f. Membangun website khusus PPID Dinas Kependudukan dan Pencatatan Sipil Kabupaten Sumedang sebagai media yang menjembatani permintaan informasi publik;

g. Membuat video animasi atau tutorial alur prosedur pelayanan setiap urusan kependudukan dan pencatatan sipil, setiap kegiatan Dinas Kependudukan dan Pencatatan Sipil Kabupaten Sumedang kemudian diunggah serta disebarluaskan melalui sosial media terutama Youtube, Facebook dan Instagram. 
(footnotes)

1. Hetifah Sj. Sumarto, Inovasi, Partisipasi, dan Good Governance (Jakarta: Yayasan Obor Indonesia, 2009), Hlm. Pengantar. Beberapa lembaga yang mendorong penyelenggaraan pemerintahan yang demokratis di Indonesia di antaranya UNDP (United Nations Development Agency), USAID (United States Agency for International Development), The Asian Foundations, Ford Foundations, World Bank, dll

2 Sedarmayanti, Good Governance: Kepemerintahan yang Baik Edisi Kedua (Bandung: Mandar Maju, 2012), Hlm. 5

3 UU KIP kepanjangan dari Undang-Undang Keterbukaan Informasi Publik, yakni Undang-Undang No. 14 Tahun 2008 tentang Keterbukaan Informasi Publik, penulis akan banyak menggunakan kata KIP dengan kependekan dari Keterbukaan Informasi Publik.

4 Open Government Indonesia (OGI) tentang OGI, https: opengovindonesia. org/keterbukaan/,diakses pada 28 Desember 2019.

5 Christian P. Geiger \& Jorn Von Lucke, Open Government and Linked Open Government Data (Journal of e-Democracy, 2012), Hlm. 265

6 Yashinta Difa, Derita Nelayan Seiring Reklamasi Pantai Jakarta, https: //www. antaranews.com/berita/554994/deritanelayan-seiring-reklamasi-pantai-jakarta, di-upload pada 13 April 2016

7 PPID merupakan pelaksana utama pengeloaan informasi dan dokumentasi yang bertanggunjawab dalam mewujudkan pelayanan informasi secara tepat, sederhana, dan cepat sebagai pemeran utama dalam keberhasilan implementasi UU KIP.

8 Lihat penjelasan UU KIP Pasal 1 ayat 9

9 Undang-undang 23 Tahun 2014 tentang Pemerintah Daerah Pasal 12 ayat (2) menyebutkan secara eksplisit tentang pembagian urusan pemerintah nonpelayanan dasar
10 Rocky Gerung, Pemerintah ditakdirkan Di kritik 27 jam sehari. https: //wow.tribunnews. com/2018/11/10/rocky-gerungpemerintah-itu-ditakdirkan-untukdikritik-kalau-bisa-27-jam-sehari diakses pada 11 Januari 2020

11 https: //www.lapor.go.id/instansi/pemerintah-kabupaten-sumedang

12 Wayne Parsons, Public Policy: Pengantar Teori dan Praktik Analisis Kebijakan dialihbahasakan oleh Tri Wibowo Budi Santoso (Jakarta: Kencana,2011), Hlm. 73

13 Norman K. Denzin dan Yvonna S. Lincoln, Strategies of Qualitative Inquiry (California: Sage, 1994), hal. 109.

14 Sugiyono, Metode Penelitian Kuantitatif Kualitatif dan R\&D (Bandung: Alfabeta,2014), Hlm. 8

15 Moh. Nazir, Op. Cit., hlm. 74.

16 Juliansyah Noor, Metodologi Penelitian, (Jakarta: Prenada Media, 2014), hlm. 111.

17 Merilee S. Grindle, Op.Cit., HIm 11

18 Merilee S. Grindle, Op. Cit., Hlm. 6

19 UU Keterbukaan Informasi Publik, Pasal 3

20 https: //mti.binus.ac.id/2017/07/03/ penyalahgunaan-informasiberita-hoax-di-media-sosial/

21 https: //kominfo.jatimprov.go.id/read/ umum/hoax-muncul-karena-penyalahgunaan-teknologi-informasi

22 Perbup Sumedang No. 97 Tahun 2017 Pasal 5 ayat (1), pada poin (d)

23 Merilee S. Grindle, Op. Cit. Hlm 111

24 Open Government Partnership, Right to information, https: //www. opengovguide.com/topics/right-toinfo/2015, diakses pada 20 Desember 2019.

25 Ibid Hal 63 


\section{DAFTAR RUJUKAN}

Abidin, Said Zaenal. 2012. Kebijakan Publik edisi ke-2. Jakarta: Salemba Humanika.

Arikunto. 2006. Prosedur Penelitian Suatu Pendekatan Praktik. Jakarta: Rineka Cipta

Creswell, John W. 2007. Qualitative Inquiry \& Research Design: Choosing Among Five Approaches (Second Edition). California: Sage Publication, Inc

Dunn N, William. 2008. Analisis Kebijakan Publik. Penyadur: Muhadjir Darwin, Yogyakarta: PT Hanindita Graha Widya

Dwiyanto, Agus. 2008. Mewujudkan Good Governance Melalui Pelayanan Publik. Yogyakarta: Gajah Mada University Press.

Grindle, Merilee S. 1980. Politics and Policy Implementation in The Third World. USA: Princeton University Press.

Winarno, Budi. 2005. Teori \& Proses Kebijakan Publik. Yogyakarta: Media Pressindo.

\section{Jurnal}

Indah, Tiara \& Puji Hariyanti. 2018. Implementasi Kebijakan Keterbukaan Informasi Publik Pada Dinas Kominfo Kota Tasikmalaya. Universitas Islam Indonesia

Pambayun, Kuncoro Galih. 2017. Analisis Implementasi Keterbukaan Informasi Publik Pada Dinas Perpustakaan Provinsi Jawa Barat. Pascasarjana Institut Pemerintahan Dalam Negeri

\section{Peraturan Perundang-Undangan}

Undang-Undang No. 14 Tahun 2008 tentang Keterbukaan Informasi Publik.

Peraturan Bupati Sumedang No. 97 Tahun 2017 tentang Pengelolaan Pelayanan Informasi dan Dokumentasi Pemerintahan Daerah

Keputusan Bupati Sumedang No. 482/Kep.148HUK/2015 Perubahan atas Peraturan Bupati Sumedang No. 52 Tahun 2014 ttg PPID di Lingkungan Pemerintah Kab. Sumedang

\section{Website}

Open Government Indonesia (OGI) tentang OGI, https: opengovindonesia.org/ keterbukaan/, Open Government Partnership, Adopt a law which recognises the right to information, in line with international standards, https: //www. opengovguide.com/commitments / adopt-a-law-which-recognises-theright-to-information-in-line-withinternational-standards/,

Website LAPOR Sumedang https: //www.lapor. go.id/instansi/pemerintah-kabupatensumedang 
Virioner - Vol. $13 \backslash$ No. $2 \backslash$ Agustus 2021 